Review

\title{
Arsenic-Induced Genotoxicity and Genetic Susceptibility to Arsenic-Related Pathologies
}

\author{
Francesca Faita, Liliana Cori, Fabrizio Bianchi and Maria Grazia Andreassi * \\ Institute of Clinical Physiology, CNR, via Moruzzi 1, Pisa 56124, Italy; \\ E-Mails: francesca.faita@ifc.cnr.it (F.F.); liliana.cori@ifc.cnr.it (L.C.); fabrizio.bianchi@ifc.cnr.it (F.B.) \\ * Author to whom correspondence should be addressed; E-Mail: andreas@ifc.cnr.it; \\ Tel.: +39-050-315-2628; Fax: +39-050-315-2166.
}

Received: 25 February 2013; in revised form: 22 March 2013 / Accepted: 3 April 2013 /

Published: 12 April 2013

\begin{abstract}
The arsenic (As) exposure represents an important problem in many parts of the World. Indeed, it is estimated that over 100 million individuals are exposed to arsenic, mainly through a contamination of groundwaters. Chronic exposure to As is associated with adverse effects on human health such as cancers, cardiovascular diseases, neurological diseases and the rate of morbidity and mortality in populations exposed is alarming. The purpose of this review is to summarize the genotoxic effects of As in the cells as well as to discuss the importance of signaling and repair of arsenic-induced DNA damage. The current knowledge of specific polymorphisms in candidate genes that confer susceptibility to arsenic exposure is also reviewed. We also discuss the perspectives offered by the determination of biological markers of early effect on health, incorporating genetic polymorphisms, with biomarkers for exposure to better evaluate exposure-response clinical relationships as well as to develop novel preventative strategies for arsenic- health effects.
\end{abstract}

Keywords: arsenic; biomarkers; genotoxicity; genetic polymorphisms

\section{Introduction}

Chronic arsenic exposure is an important problem to human health in many parts of the World. Indeed, over 100 million individuals worldwide are exposed to arsenic, mainly through contamination of groundwaters [1]. Arsenic is a metalloid element and exists in organic and inorganic forms. 
Inorganic arsenic (iAs) is a class I human carcinogen [2] and is associated with adverse effects dependent on dose, duration and exposure frequency. In particular chronic exposure to iAs is associated to an increased risk of skin, bladder, lung, kidney cancers, as well as cardiovascular and neurological diseases, diabetes and non-malignant respiratory diseases [2].

The pathogenic mechanisms of iAs related to development of these pathologies are very complex and likely multifactorial. One of principal mechanisms of arsenic toxicity is the induction of a strong oxidative stress with production of free radicals in cells [3]. Indeed, there is increasing evidence that the induction of reactive oxygen species (ROS) plays a crucial role in arsenic toxicity. Several studies have shown that populations chronically exposed to arsenic have significant oxidative stress that, in turn, induces DNA damage [4-6], as well as lipid peroxidation and decreased glutathione levels [7,8]. Moreover, the arsenic-induced ROS generation has been related with alteration of signaling pathways inside the cells and transcription factors regulation, which are two mechanisms that play a crucial role in carcinogenesis [9]. In particular, a very recent study has observed that chronic exposure of humans to low levels of arsenic selectively induces oxidative DNA damage of peripheral blood polymorphonuclear cells, increasing and accelerating apoptosis of these cells [10]. Furthermore, interestingly, prenatal arsenic exposure has been associated with oxidative stress in cord blood and with a reduced thymic function, suggesting subsequent immunosuppression in childhood [11]. The oxidative stress induced by arsenic exposure derives mainly from iAs metabolism. Indeed, it has been proposed that the biotrasformation of iAs generates final and intermediate metabolites exhibiting higher toxicity and reactivity compared to the originally ingested iAs [12-14]. In the environment iAs can be found in several oxidation states, i.e., as trivalent (iAS ${ }^{\mathrm{III}}$ or arsenite) and pentavalent (iAs ${ }^{\mathrm{V}}$ or arsenate) species [15]. These forms are differently metabolized by mammals and exhibit distinct grades of toxicity. Particularly, the trivalent form is known to be more toxic than the pentavalent form [16].

In the organism arsenic metabolism may follow two possible pathways: classical reduction and oxidative methylation by the action of arsenic $\left(3^{+}\right.$oxidation state) methyltransferase enzyme (ASIIIMT) or a glutathione (GSH) conjugation [1]. In both of these pathways, the end products are monomethylated and dimethylated arsenic metabolites, such as methylarsonic acid $\left(\mathrm{MMA}^{\mathrm{V}}\right.$ and $\mathrm{MMA}^{\mathrm{III}}$ ) and dimethylarsinic acid $\left(\mathrm{DMA}^{\mathrm{V}}\right.$ and $\left.\mathrm{DMA}^{\mathrm{III}}\right)$ [1], as shown in Figure 1. Therefore, the oxidative stress induced by chronic exposure to iAs is related to cytotoxic and genotoxic effects in the cells, playing a crucial role in the pathogenesis of diseases, such as diabetes, cardiovascular and nervous systems disorders.

The purpose of this review is to summarize the genotoxic effects of iAs in the cells as well as to discuss the importance of signaling and repair of arsenic-induced DNA damage. The current knowledge of specific polymorphisms in candidate genes that confer susceptibility to arsenic exposure is also reviewed. We also discuss the perspectives offered by the determination of biological markers of early effect on health, incorporating genetic polymorphisms, with biomarkers for exposure to better evaluate exposure-response clinical relationships as well as to develop novel preventative strategies for arsenic- health effects. 
Figure 1. The metabolism pathway of inorganic arsenic showing arsenate reduction to arsenite and methylation to pentavalent and trivalent forms.

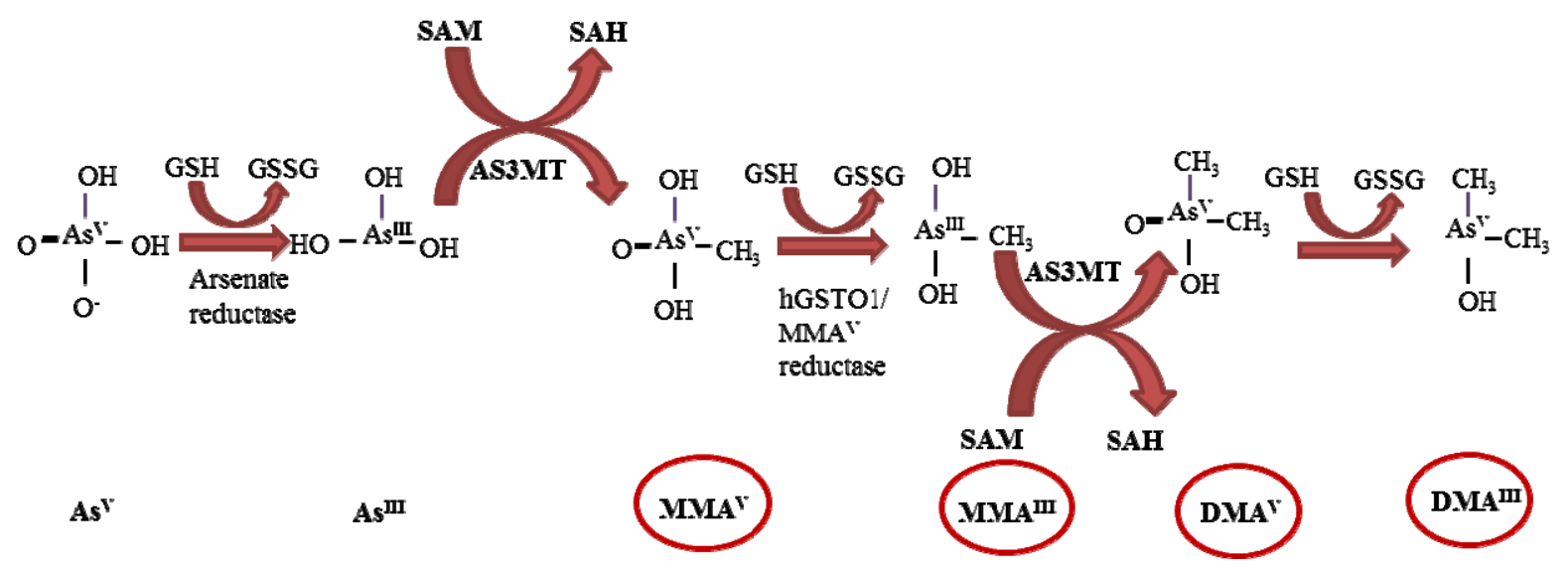

\section{Genotoxicity}

The genotoxic role of iAs in the cells has long been controversial. Arsenic is reported to cause DNA modifications such as aneuploidy, micronuclei formation, chromosomal aberrations, deletion mutations, sister chromatid exchange and DNA-protein cross-linking [1]. Several mechanisms have been proposed to explain the genotoxicity of arsenic, as well as induction of oxidative stress and altered patterns of DNA repair [15].

\subsection{DNA Damage}

It has been demonstrated that arsenic does not react directly with DNA [17] and is considered a poor mutagen, as indeed it fails to cause point mutations characteristic of any classical mutagen [1]. However, despite its low capacity to cause mutations, it affects the mutagenicity of other carcinogens (Figure 2). For instance, a synergistic increase in the mutagenic activity of arsenic with UV light has been observed in mammalian and human cells, after exposing the UV-treated cells to arsenic [18,19].

A series of experimental observations suggest that the arsenic genotoxicity is primarily linked to the generation of ROS during its biotransformation [20-22]. The ROS production is able to generate DNA adducts; DNA strand breaks, crosslinks and chromosomal aberrations [23-25]. The principal mechanism of genetic damage induced by arsenic is via oxidative mechanism (Figure 2).

One of principal effects of oxidative damage to DNA is the DNA base modification. In particular 8-oxoguanine (8-OHdG) is one of most frequently formed DNA nucleobase modifications and is often used in epidemiological studies as a marker for oxidative stress [26,27]. 8-Oxoguanine is a highly mutagenic miscoding lesion that can lead to $\mathrm{G}: \mathrm{C}$ to $\mathrm{T}$ :A trasversion mutations [28]. The presence of oxidative DNA adducts 8-OHdG upon arsenic exposure has been documented in several tissues [29,30].

Recently, urinary 8-OHdG levels were correlated with individual total arsenic level in a human population with low exposure to arsenic and might be indicative of arsenic-induced renal cell carcinoma [31]. Moreover, iAs can induce DNA strand breaks even at low concentrations [15]. Arsenic-induced single-strand breaks are caused either directly by ROS on the DNA bases or indirectly during the course of base excision repair (BER) mechanism [32]. It was observed that human fibroblast cells exposed to iAs exhibit ssDNA breaks and DNA-protein adducts, as well as chromatid 
exchange [33]. Furthermore, the treatment with $\mathrm{O}_{2}^{-}$scavengers and other antioxidants reduce arsenic-induced DNA strand breaks in aortic cells confirming the role of ROS production in the process [34]. In this context it was observed that $1 \mu \mathrm{M}$ of iAs increases UVR-mediated DNA strand breaks by interfering with Poly-adenosine diphosphate-ribose polymerase 1 (PARP-1) activity, a protein with an important role in the ssDNA and dsDNA break repair process [35].

Figure 2. Schematic representation of arsenic genotoxicity.

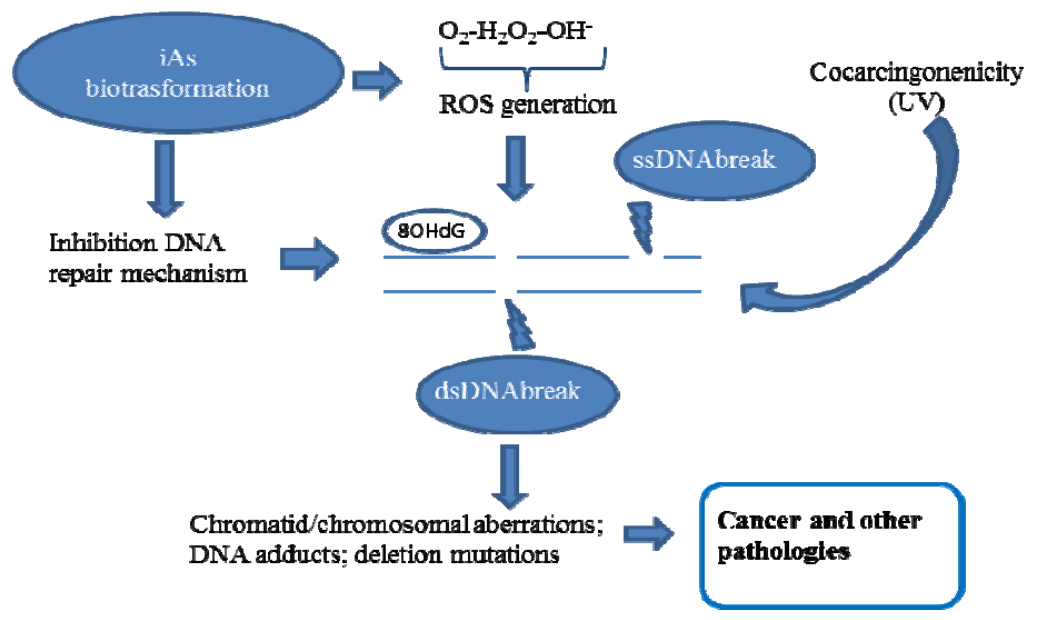

\subsection{Chromatid and Chromosomal and Telomere Damage}

Arsenic is a known inducer of chromosomal and chromatid aberrations and this involves both clastogenic and aneuploidogenic effects [36]. In recent years several studies have performed cytogenetic monitoring by using chromosomal aberrations assay (CA), micronuclei assay (MN) and Sister Chromatid assay (SCE) in order to detect the genotoxic effects in different population exposed to arsenic, as summarized in the Table 1.

These studies have observed an increase of incidence of CA in individuals with chronic exposure to arsenic [37-40]. Moreover, it has been observed an increase of frequency of $\mathrm{MN}$ in peripheral lymphocytes and in buccal and urothelial cells in exposed individuals in comparisons with a control population. In a study in West Bengal, India, a country with high arsenic contamination, the frequencies of micronuclei in oral mucosal cells, urothelial cells and peripheral lymphocytes were found to be significantly high in exposed participants, compared with unexposed control participants [41]. In Chile Martinez et al. have shown a significant increase in the frequencies of MN in peripheral blood lymphocytes of exposed individuals [40]. Furthermore, many studies used buccal epithelial in order to validate this biomarker of genotoxicity demonstrating an increase of $\mathrm{MN}$ frequencies in people exposed to As in comparisons with a control population [37,40,42-47]. Altogether, these studies showed that chromosomal biomarkers, especially $\mathrm{MN}$ and CA, are sensitive biomarkers of early biological effects of iAs exposure [48]. Indeed, only a few studies found weak or no cytogenetic effects in exposed individuals exposed, probably due to the small number of individuals analyzed [49-51]. During recent years, large studies have provided consistent evidence that high levels of chromosomal DNA damage in peripheral blood lymphocytes are early predictors of cancer risk and cardiovascular disease [52-54]. 
Table 1. Cytogenetic monitoring in populations exposed to arsenic.

\begin{tabular}{|c|c|c|c|c|}
\hline $\begin{array}{c}\text { Study population, } \\
\text { n }\end{array}$ & $\begin{array}{c}\text { Mean arsenic } \\
\text { water drinking } \\
\text { exposure }\end{array}$ & Country & Main endpoint result & References \\
\hline $\begin{array}{l}18 \text { exposed subjects } \\
18 \text { controls }\end{array}$ & $\begin{array}{l}1,312 \mu \mathrm{g} / \mathrm{L} \\
16 \mu \mathrm{g} / \mathrm{L}\end{array}$ & Nevada & $\begin{array}{l}1.8 \text { fold increase in bladder cells } \\
\mathrm{MN} \text { correlation/iAs urinary level }\end{array}$ & Warner et al. [54] \\
\hline $\begin{array}{l}31 \text { exposed subjects } \\
27 \text { controls }\end{array}$ & $\begin{array}{l}408.7 \mu \mathrm{g} / \mathrm{L} \\
29.88 \mu \mathrm{g} / \mathrm{L}\end{array}$ & Mexico & $\begin{array}{l}\text { CA increase in lymphocytes } \\
\text { MN increase in oral and urinary } \\
\text { cells }\end{array}$ & $\begin{array}{l}\text { Gonsebatt et al. } \\
{[44]}\end{array}$ \\
\hline $\begin{array}{l}42 \text { exposed subjects } \\
8 \text { controls }\end{array}$ & $\begin{array}{l}410 \mu \mathrm{g} / \mathrm{L} \\
<1 \mu \mathrm{g} / \mathrm{L}\end{array}$ & Finland & $\begin{array}{l}\text { CA correlation/urinary As } \\
\text { exposure, among current users }\end{array}$ & $\begin{array}{l}\text { Maki-Paakanen } \\
{[50]}\end{array}$ \\
\hline $\begin{array}{l}19 \text { exposed subjects } \\
13 \text { controls }\end{array}$ & $\begin{array}{l}527.5 \mu \mathrm{g} / \mathrm{L} \\
4.4 \mu \mathrm{g} / \mathrm{L}\end{array}$ & USA & $\begin{array}{l}3.4 \text { fold increase of } \mathrm{MN} \text { in buccal } \\
\text { cells } \\
2.7 \text { fold increase in bladder cells }\end{array}$ & Tian $[45]$ \\
\hline $\begin{array}{l}32 \text { cancer cases of } \\
\text { risk area } \\
32 \text { controls of } \\
\text { risk area }\end{array}$ & n.d. & Taiwan & $\begin{array}{l}\text { No difference in spontaneous and } \\
\text { mitomycin C-induced SCE }\end{array}$ & Liou et al. [49] \\
\hline $\begin{array}{l}45 \text { exposed subjects } \\
21 \text { controls }\end{array}$ & $\begin{array}{l}368.11 \mu \mathrm{g} / \mathrm{L} \\
5.49 \mu \mathrm{g} / \mathrm{L}\end{array}$ & India & $\mathrm{MN}$ increase & Basu et al. [42] \\
\hline $\begin{array}{l}59 \text { exposed subjects } \\
36 \text { controls }\end{array}$ & $\begin{array}{l}211.70 \mu \mathrm{g} / \mathrm{L} \\
6.35 \mu \mathrm{g} / \mathrm{L}\end{array}$ & India & $\mathrm{CA}$ and $\mathrm{SCE}$ increases & Mahata et al. [39] \\
\hline $\begin{array}{l}106 \text { exposed } \\
\text { subjects } \\
111 \text { controls }\end{array}$ & $\begin{array}{l}>750 \mu \mathrm{g} / \mathrm{L} \\
>2 \mu \mathrm{g} / \mathrm{L}\end{array}$ & Chile & MN increase & $\begin{array}{l}\text { Martinez et al. } \\
\text { [40] }\end{array}$ \\
\hline $\begin{array}{l}163 \text { exposed } \\
\text { subjects } \\
154 \text { controls }\end{array}$ & $\begin{array}{l}214.7 \mu \mathrm{g} / \mathrm{L} \\
9.2 \mu \mathrm{g} / \mathrm{L}\end{array}$ & India & $\begin{array}{l}5.3 \text { fold MN increase in } \\
\text { lymphocytes } \\
4.6 \text { fold MN increase in oral cells } \\
4.7 \text { fold MN increase in urothelial } \\
\text { cells }\end{array}$ & Basu et al. [41] \\
\hline $\begin{array}{l}45 \text { exposed subjects } \\
25 \text { controls }\end{array}$ & $\begin{array}{l}66.75 \mu \mathrm{g} / \mathrm{L} \\
6.4 \mu \mathrm{g} / \mathrm{L}\end{array}$ & India & $\mathrm{CA}$ and $\mathrm{MN}$ increases & $\begin{array}{l}\text { Chakraborty et al. } \\
\text { [43] }\end{array}$ \\
\hline $\begin{array}{l}422 \text { exposed } \\
\text { subjects }(244 \text { skin } \\
\text { symptomatic) } \\
120 \text { controls }\end{array}$ & $\begin{array}{l}202.33 \mu \mathrm{g} / \mathrm{L} \\
7.16 \mu \mathrm{g} / \mathrm{L}\end{array}$ & India & $\mathrm{CA}$ and $\mathrm{MN}$ increases & $\begin{array}{l}\text { Ghosh et al. } \\
{[37,38]}\end{array}$ \\
\hline $\begin{array}{l}200 \text { subjects } \\
\text { exposed } \\
165 \text { controls }\end{array}$ & $\begin{array}{l}56.76 \mu \mathrm{g} / \mathrm{L} * \\
117.4 \mu \mathrm{g} / \mathrm{L} *\end{array}$ & India & $\begin{array}{l}\text { MN increase in buccal cells } \\
\text { DNA increase in lymphocytes }\end{array}$ & Vuyyuri [44] \\
\hline $\begin{array}{l}27 \text { exposed subjects } \\
30 \text { controls }\end{array}$ & $\begin{array}{l}>50 \mu \mathrm{g} / \mathrm{L} \\
\text { (water drinking) } \\
<50 \mu \mathrm{g} / \mathrm{L} \\
\text { (water drinking) }\end{array}$ & Argentina & MN increase in buccal cells & Bartolotta [46] \\
\hline
\end{tabular}

* Occupational exposure; CA: Chromosomal Aberration; MN: Micronucleus; SCE: Sister Chromatid Exchange; n.d.: not determined.

Moreover, arsenic acts also on expression and length of telomere. In particular, it has been observed that $\mathrm{iAs}^{\mathrm{III}}$ induce telomerase stimulation at low concentrations, with major effects in female cells 
respect to male cells. On the contrary, at the concentration of $1 \mu \mathrm{M}$, iAS ${ }^{\mathrm{III}}$ decrease telomerase expression and telomere length, inducing apoptosis, necrosis and ROS production [55]. Accordingly, a study in vivo in a population exposed to arsenic has recently observed that urinary arsenic was positively correlated with the expression of telomerase reverse transcriptase and telomere length [56].

In conclusion, the use of chromosomal biomarkers may be very useful in epidemiological studies in order to provide a better surveillance of arsenic-induced health hazards in populations exposed.

\subsection{DNA Repair Inhibition}

Inhibition of DNA repair processes is considered one of main mechanism of iAs genotoxicity. Nucleotide Excision Repair (NER) and Base Excision Repair (BER) are the processes implicated in the repair of DNA base damage induced by ROS after iAs exposure. In particular the NER mechanism is the major pathway for repairing bulky distortions in DNA double helix, while the BER mechanism is mainly implicated in the repair of single strand breaks induced by RO [57]. Several studies with cultured human fibroblasts showed a reduced DNA repair capacity after iAs exposure [58,59]. Early studies about effect of iAs exposure on DNA repair mechanism proved that arsenic inhibits NER process [58,60-62].

Conversely, more recent studies demonstrated that iAs could repress the BER mechanism. [57,63]. Indeed, the BER mechanism is the predominant pathway for DNA lesions caused by ROS and it is possible that it is inhibited by iAs exposure. Sykora et al. have observed a dose-dependent down- regulation of mRNA of genes implicated in BER process such as DNA Polymerase beta (Pol beta) and apurinic/apyrimidinic endonuclease (APE1) at doses of As ${ }^{\mathrm{III}}$ above $1 \mu \mathrm{M}$. However, at lower doses Pol beta mRNA were significantly increased, exhibiting an hormetic effects [64].

Accordingly, a recent study evaluated an arsenic-induced cytotoxic and genotoxic effects under Pol beta deficiency in mouse embryonic fibroblasts. The authors have shown an increased level of DNA damage and significantly delayed DNA damage repair in Pol-beta deficient cells with As exposure, demonstrating an important role for Pol beta in repairing arsenite-induced DNA damage [57]. Moreover, transcription levels of genes related to BER mechanism are altered in lung tissue of mice exposed to iAs in a gene, age, dose and duration manner [65]. Additionally, mRNAs of DNA ligase I and III, implicated in BER mechanisms are significantly reduced in mammalian cells in response to $\mathrm{As}^{\mathrm{III}}[66]$.

Changes in the BER and NER genes expression levels have been also demonstrated in human exposed populations. Arsenic exposure was associated with decreased expression of the excision repair cross-complementing rodent repair deficiency, complementation group 1 (ERCC1), of the xeroderma pigmentosum group B (XPB) and of the xeroderma pigmentosum group F (XPF) genes in isolated lymphocytes from individuals exposed [59]. A decreased expression of ERCC1 gene at the mRNA and protein levels was also observed among individuals exposed to low dose of arsenic [60].

Recently, Ebert et al. have investigated the impact of arsenic on several BER genes in cultured human lung cells, comparing the effects of inorganic arsenite and its trivalent and pentavalent mono and dimethylated metabolites. They have found that arsenite and its metabolites can affect several cellular endpoints related to DNA repair. In particular cellular activity of human 8-oxoguanine DNA glycosylase (hOGG1) was most sensitively affected by DMA ${ }^{\mathrm{V}}$; DNA ligase $\mathrm{III}_{\alpha} \mathrm{LIGIII}_{\alpha}$ ) protein level by arsenite and X-ray cross complementing protein 1 (XRCC1) by $\mathrm{MMA}^{\mathrm{V}}$ [63]. 


\section{Genetic Susceptibility to Arsenic Toxicity}

Recently, epidemiological studies have observed that there is a high inter-individual variability in the susceptibility to arsenic toxicity [1]. This suggests a major role of underlying genetic factors as a cause of this variability. In this regard several studies demonstrated the influence of specific genetic polymorphisms in genes encoding enzymes involved in mechanisms of As metabolism and detoxification, including arsenic(III) methyltransferase (ASIIIMT), glutathione S-transferases (GST) and methylenetetrahydrofolate reductase (MTHFR) enzymes [67-69]. Moreover, specific single nucleotide polymorphisms (SNPs) in genes of DNA repair pathways (e.g., hOGG1, APE1, XRCC1, XRCC3 genes) have been shown to reduce the capacity to repair the oxidative damage induced by IAs [70,71] (Table 2).

Table 2. Genetic polymorphisms involved in the susceptibility to arsenic toxicity.

\begin{tabular}{|c|c|c|c|c|}
\hline Gene symbol & $\begin{array}{l}\text { Biological } \\
\text { function }\end{array}$ & SNP & Main associated effect & References \\
\hline ASIIIMT & As metabolism & $\begin{array}{l}\text { G7395A (intronic) } \\
\text { T35587C(intronic) } \\
\text { G12390C(intronic) } \\
\text { C14215T(intronic) } \\
\text { Met287Thr } \\
\text { A35991G (intronic) }\end{array}$ & Arsenic metabolite levels & $\begin{array}{l}\text { Meza et al. }[72] \\
\text { Schläwicke Engström et al. } \\
{[69]} \\
\text { Hernandez et al. }[73] \\
\text { Lindberg et al. }[74] \\
\text { Agusa et al. }[75] \\
\text { Gong et al. }[76]\end{array}$ \\
\hline GST-O2 & $\begin{array}{c}\text { As } \\
\text { detoxification }\end{array}$ & $\begin{array}{l}\text { Asn142Asp } \\
\text { Ala140Asp }\end{array}$ & $\begin{array}{l}\text { iAs and arsenic metabolites } \\
\text { levels } \\
\text { Major risk of carotid } \\
\text { atherosclerosis }\end{array}$ & $\begin{array}{l}\text { Chung et al. }[68] \\
\text { Chen et al. }[77] \\
\text { Hsieh et al. }[78]\end{array}$ \\
\hline GST-P1 & $\begin{array}{c}\text { As } \\
\text { detoxification }\end{array}$ & Ile105Val & $\begin{array}{l}\text { Arsenic metabolite levels } \\
\text { Major risk of TCC } \\
\text { Major risk of bladder cancer } \\
\text { Major risk of carotid } \\
\text { atherosclerosis }\end{array}$ & $\begin{array}{l}\text { Agusa et al. }[79] \\
\text { Hsu et al. }[80,81] \\
\text { Lesseur et al. [82] } \\
\text { Wang et al. [83] }\end{array}$ \\
\hline GST-M1 & $\begin{array}{c}\text { As } \\
\text { detoxification }\end{array}$ & Null genotype & $\begin{array}{l}\text { iAs and arsenic metabolite } \\
\text { levels }\end{array}$ & $\begin{array}{l}\text { Chiou et al. [84] } \\
\text { Steinmaus et al. [85] }\end{array}$ \\
\hline GST-T1 & As detoxification & null genotype & Arsenic metabolite levels & Chiou et al. [86] \\
\hline MTHFR & As metabolism & Ala222Val & $\begin{array}{l}\text { iAs and arsenic metabolite } \\
\text { levels }\end{array}$ & $\begin{array}{l}\text { Lindberg et al. }[74] \\
\text { Schläwicke Engström et al. } \\
{[69]}\end{array}$ \\
\hline hOGG1 & DNA repair & Ser326 Cys & 8-oxoguanine levels & Fujihara et al. [70] \\
\hline APE1 & DNA repair & Asp148Glu & 8-oxoguanine levels & Fujihara et al. [70] \\
\hline $\mathrm{XRCC} 3$ & DNA repair & Thr241Met & $\begin{array}{l}\text { Arsenic-induced skin } \\
\text { lesions; Chromosomal } \\
\text { aberrations }\end{array}$ & Kundu et al. [71] \\
\hline $\mathrm{HO} 1$ & $\begin{array}{l}\text { Inducible } \\
\text { antioxidant } \\
\text { enzyme }\end{array}$ & short GT-repeat & $\begin{array}{l}\text { BP regulation and } \\
\text { cardiovascular mortality risk }\end{array}$ & Wu et al. $[87,88]$ \\
\hline P53 & $\begin{array}{c}\text { Tumor } \\
\text { suppressor }\end{array}$ & Arg72Pro & $\begin{array}{l}\text { Risk for arsenic-induced } \\
\text { kerastosis } \\
\text { Risk for renal cell carcinoma }\end{array}$ & $\begin{array}{l}\text { De Chaudhuri et al. [89] } \\
\text { Huang et al. [90] }\end{array}$ \\
\hline
\end{tabular}




\subsection{ASIIIMT Genetic Polymorphisms}

ASIIIMT is an S-adenosyl-methionine-dependent enzyme that catalyzes the methylation of arsenite and plays a fundamental role in arsenic metabolism. The human AS3MT gene is approximately $32 \mathrm{~kb}$ long and is composed of 11 exons [91]. Several studies have shown that polymorphisms in the AS3MT gene are associated with the efficiency of arsenic biotransformation and cancer risk [67,68]. In 2005, Meza et al. showed that three SNPs in introns (G7395A, G12390C and T35587C) were significantly associated with the urinary DMA[V]/MMA[V] ratio in Mexican children [72]. Subsequently, three intronic variant alleles (G12390C, C14215T and A35991G) were found associated with a lower percentage of MMA and a higher percentage of DMA in urine of Argentinians. This study has showed that the presence of these SNPs leads to a higher ratio for second methylation step that converts MMA to DMA [69]. Conversely, the study of SNP A35991G has shown that homozygosity 35991AA was associated with a lower percentage of DMA in urine compared to other genotypes in Vietnamese [75].

Interestingly, different studies have reported that several of these SNPs are in strong linkage-disequilibrium (LD) which also extends to a nearby gene, CYP17A1, forming a large LD cluster in chromosome 10 [73]. Genetic association analysis with As metabolism confirmed a significant association between AS3MT variants in this cluster of linked polymorphisms and arsenic methylation efficiency [73]. Moreover, a recent study has established an association between hypertension, hyperlipidemia, As exposure and SNP A35991G of ASIIIMT gene. In particular hyperlipidemia was associated with genotype AG vs. AA of ASIIIMT gene [76].

With regard to genetic variants in the exons, it has been reported that three non-synonymous SNPs (A173W; M287T and T306I) in the ASIIIMT gene significantly alter the levels of enzyme activity and immunoreactive proteins [69]. Among these SNPs the M287T polymorphism is considered to be related to inter-individual variation in the arsenic metabolism [92]. Indeed, in Chile, has been observed that the individuals with one variant allele have a percentage of MMA in urine 8.63 times higher than the individuals with the wild genotype, and that individuals with both variant alleles have twice this MMA increment [93]. A similar result was reported in the central European population [74]. In particular the carriers of the variant allele of the M287T $(C \rightarrow T)$ polymorphism had a higher methylation capacity of the enzyme and therefore a higher percentage of MMA metabolite in urine.

These studies showed that the presence of the SNP M287T in gene of ASIIIMT is associated with a higher enzymatic activity of ASIIIMT and alters the standard profile of the urinary metabolites of arsenic, leading to a higher MMA percentage and a higher risk to develop arsenic-related cancers. Moreover, the presence of variant allele of the M287T has been also associated with a major risk to develop carotid atherosclerosis [78].

Accordingly, a recent review summarized genetic studies and findings regarding ASIIIMT SNPs and highlighted that two SNPs (Met287Thr and G12390C) were consistently related to arsenic methylation across diverse populations [94]. Finally, a recent first genome-wide association study (GWAS) of arsenic-related metabolism and toxicity using 30.000 genome-wide SNPs in 1.313 arsenic-exposed Bangladeshi individuals identified genome-wide significant association signals for percentages of MMA and DMA near the AS3MT gene, with five genetic variants showing independent associations [69]. 


\subsection{Polymorphisms in GSTs Genes and Other Detoxification Genes}

GSTs represent a group of enzymes that are involved in the phase II detoxifications reactions, usually by catalyzing the conjugation of reduced glutathione (GSH) into hydrophobic and electrophilic compounds along with other phase II enzymes.

Many studies have shown that these enzymes are involved in iAs metabolism. In particular four classes of cytosolic GSTs (GST-P1, GST-O1, GST-M1 and GST-T1) have been suggested to take part in iAs biotransformation. In particular several studies have examined the function of two enzymes GST-O1 and GST-O2 which are involved in the reduction of arsenate to arsenite $[95,96]$ by investigating the relationship between GST-O polymorphisms and variation in arsenic methylation. In most studies significant association and, thus, consistent conclusions, have not been found $[1,74,97]$. However, a recent study in Taiwan showed that the GST-O2 Asn142Asp variant is associated with an increased iAs\% [68] and with major risk of arsenic-related bladder cancer [82], while in another study GST-O1 A140D polymorphism is associated with a lower MMA\% [77]. Additionally, a marked elevated risk of carotid atherosclerosis was observed in subjects with high arsenic exposure and GSTO risk haplotypes [78].

Furthermore, an increased expression of GST-P1 has been observed in several arsenic-resistant cell lines, suggesting that this enzyme may have an important function in arsenic toxicity [98,99]. In addition, GSTP1 is a polymorphic gene, and the GST-P1 Ile105Val variant influences the geometry of the hydrophobic binding site of GSTP1 enzyme resulting in differences in enzyme specificity and activity [100].

Interestingly, in a Vietnamese population, lower reduction capacity and a lower percentage of urinary As ${ }^{\mathrm{III}}$ was observed for Val allele carriers compared to wild-type individuals [79]. Moreover, in another study a gene-environment interaction with this SNP has been observed, showing that individuals homozygous for Val allele with high arsenic exposure had a major risk of bladder cancer [82]. This result is according to two previous studies reporting a major risk of urinary transitional cell carcinoma (TCC) in high arsenic exposed individuals with Val allele compared to wild-type individuals $[80,81]$. Moreover, Ile105Val variant has been associated with carotid atherosclerosis in population of Taiwan. In particular, a significant joint effect of this variant of GSTP and high arsenic exposure on the risk of developing carotid atherosclerosis was found [83].

Finally, genetic polymorphisms in GST-T1 and GST-M1 has been associated with distinct urinary profiles of arsenic metabolites in populations chronically exposed to iAs $[1,86,101]$. In particular, a study in Taiwan has shown that individuals with the null genotype of GSTM1 had an increased percentage of inorganic arsenic in urine, whereas those with null genotype of GSTT1 had elevated percentage of DMA in urine [84]. Accordingly, a study showed that Argentinian women with null genotype of GSTM1 had a significantly higher proportion of MMA in urine than women with wild-type genotype [85]. However, other studies didn't confirm these results: in West Bengal a higher GSTM1 null gene frequencies in asymptomatic individuals than skin symptomatic participants has been observed, and no association was observed for allelic variants in GSTT1 in the two groups [37].

Finally, enzymes involved in the one-carbon metabolism as MTHFR may also indirectly influence the metabolism of arsenic. Recently, the polymorphism A222V of MTHFR gene (associated with reduced enzyme activity) was related with higher \%MMA in urine in central European population [74]. 
Moreover in Argentinian individuals with one or two 222Val allele of MTHFR had lower \%DMA and higher \% iAs and \%MMA, compared with the wild type [1]. In order to confirm the influence of MTHFR in metabolism of arsenic, a very recent study has shown that bladder cancer cases in individuals exposed to As were also 60\% less likely to be homozygotes for the A allele in MTHFR gene compared to controls [102].

\subsection{SNPs in Genes of DNA Repair}

Arsenic causes DNA damage and changes the cellular capacity for DNA repair. Therefore, inter-individual variations in DNA repair capacity/efficiency linked to the presence of polymorphisms in DNA repair-related genes may account for different risk of developing damage inducted by arsenic. The base excision repair (BER) pathway is considered an important pathway involved in repair of DNA damage induced by reactive oxygen species. Genetic variants in BER pathway such as hOGG1, XRCC3, XRCC1 and APE1 may modulate and therefore alter the genotoxicity of arsenic. For instance, individuals with hOGG1 326Cys/Cys showed significantly higher urinary 8-OHdG concentrations than did those with $326 \mathrm{Ser} / \mathrm{Cys}$ and Ser/Ser in arsenic-exposed Vietnamese, as well for APE1 Asp148Glu, heterozygous subjects as compared to homozygous for Asp/Asp [70]. These results are consistent with previous studies showing lower activity of hOGG1 Cys326 allele [103] and a decreased ability to repair oxidative damage of APE1 variant allele (Glu) [104]. Furthermore, a significant interaction between the genotype and arsenic exposure has been observed for arsenic-related urinary transitional cell carcinoma [80]. Finally, a recent study showed that the variant T241M in XRCC3 gene is associated with a decreased incidence of arsenic-induced skin lesions and a lower level of chromosomal aberrations in individuals exposed to arsenic [71].

\subsection{Genetic Variants in Other Genes Implicated in Arsenic Susceptibility}

Inorganic arsenic has been associated with an increased risk of atherosclerotic vascular disease and cardiovascular mortality [105]. Therefore, many researchers have placed their attention on the study of polymorphisms in genes implicated in the pathogenesis of these diseases. HO-1, a gene involved in adaptive response of the vessel wall to oxidative stress, has been proposed as a protective mode in the progression of atherosclerotic vascular disease [106]. The 5'-flanking region of the gene contains a segment of GT-repeats of varying length; the number of GT repeats have been shown to influence the expression level of the gene [107]. Furthermore, it has been observed that arsenic is a strong inducer of HO-1 expression in cell cultures [108]. Therefore, several studies have shown an association between this genetic polymorphism and hypertension, carotid atherosclerosis and cardiovascular mortality. In particular, it has been observed a protective role of HO-1 short GT-repeat variants in the pathogenesis of these diseases in arsenic exposed populations [87,88].

Finally, several reports have studied the association of polymorphisms in tumor suppressor gene p53 and arsenic-related clinical effects. In West Bengal, the association of three polymorphisms of p53 (codon 72 Arg/Pro; 16-bp duplication at intron 3 and G > A at intron 6) and arsenic-induced kerastosis has been studied, showing that the arginine homozygous genotype at codon 72 and/or homozygous genotype at intron 3 are associated with at increased risk for the development of arsenic-induced kerastosis [89]. Recently, it has been observed that subjects with the p53 codon 72 Pro/Pro genotype 
had a significantly higher renal cell carcinoma (RCC) risk than those with p53 Arg allele [106]. Moreover, individuals with p53 Arg/Arg genotype had a lower percentage of inorganic arsenic and a significantly higher percentage of DMA, which means a better arsenic methylation capacity [90].

\section{Conclusions and Future Perspectives}

Arsenic has a strong genotoxic potential and is able to cause DNA damage such as aneuploidy; micronuclei formation, chromosomal aberrations, deletion mutations, sister chromatid exchange and DNA-protein cross-linking. Various mechanisms have been hypothesized to explain the cause of this DNA damage, but further studies are needed to establish the mechanism on the basis of the genetic damage induced by arsenic in order to develop specific treatment strategies for the disorders arsenic-related. Furthermore, epidemiological studies have observed that there is an high inter-individual variability in the susceptibility to arsenic-induced toxicity. Several studies have established the influence of genetic polymorphisms on susceptibility to arsenic through their modulation of As metabolism, detoxification and DNA repair.

Further studies are also required in order to gain a deeper understanding of the health impact of arsenic, and to developing specific therapeutic strategies for the arsenic-related diseases. In general the application of biomarkers in molecular-epidemiological researches constitutes a promising new strategy for enhancing exposure assessment as well as for a better understanding of the mechanisms of action and dose-response relationships for arsenic exposure and human health risk. Indeed, future insights into the arsenic-health risks of require a more accurate characterization of individual exposure and improved knowledge of arsenic-related exposures with early clinical effects. Biomarkers of effect (e.g., methylation changes, chromosomal damage, telomere shortening) indicate early signals of biologic effects preceding disease and/or predict the development and presence of disease. They can also provide individual-based data identifying high-risk groups of overexposed or hypersusceptible subjects. We believe that, in future, the evaluation of the relationship between human exposure to arsenic, estimated using environmental data and assessed through indicators of absorbed dose and biological markers of early effect on health, incorporating genetic polymorphisms will be an important strategy in order to identify identifying at-risk susceptible or resistant subpopulations.

The use of an integrated approach of environmental monitoring and human biomarkers will be able to provide important mechanistic insight into the pathogenesis of disease processes and reduce the time gap exposure and recognition of disease-relevant effects, allowing to develop new and more effective strategies to reduce risk, such as exposure monitoring, health surveillance and individual risk characterization.

\section{Conflicts of Interest}

The authors declare no conflict of interest. 


\section{References}

1. Pierce, B.L.; Kibriya, M.G.; Tong, L.; Jasmine, F.; Argos, M.; Roy, S.; Paul-Brutus, R.; Rahaman, R.; Rakibuz-Zaman, M.; Parvez, F.; et al. Genome-wide association study identifies chromosome 10q24.32 variants associated with arsenic metabolism and toxicity phenotypes in Bangladesh. PLoS Genet. 2012, 8, e1002522, doi: 10.1371/journal.pgen.1002522.

2. IARC Working Group on the Evaluation of Carcinogenic Risks to Humans. Some drinking-water disinfectants and contaminants, including arsenic. IARC Monogr. Eval. Carcinog. Risks. Hum. 2004, 84, 1-477.

3. Flora, S.J. Arsenic-induced oxidative stress and its reversibility. Free Radic. Biol. Med. 2011, 51, 257-281.

4. Basu, A.; Som, A.; Ghoshal, S.; Mondal, L.; Chaubey, R.C.; Bhilwade, H.N.; Rahman, M.M.; Giri, A.K. Assessment of DNA damage in peripheral blood lymphocytes of individuals susceptible to arsenic induced toxicity in West Bengal, India. Toxicol. Lett. 2005, 159, 100-112.

5. Méndez-Gómez, J.; García-Vargas, G.G.; López-Carrillo, L.; Calderón-Aranda, E.S.; Gómez, A.; Vera, E.; Valverde, M.; Cebrián, M.E.; Rojas, E. Genotoxic effects of environmental exposure to arsenic and lead on children in region Lagunera, Mexico. Ann. New York Acad. Sci. 2008, 1140, $358-367$.

6. Sampayo-Reyes, A.; Hernández, A.; El-Yamani, N.; López-Campos, C.; Mayet-Machado, E.; Rincón-Castañeda, C.B.; Limones-Aguilar Mde, L.; López-Campos, J.E.; de León, M.B.; González-Hernández, S.; Arsenic induces DNA damage in environmentally exposed Mexican children and adults. Influence of GSTO1 and AS3MT polymorphisms. Toxicol. Sci. 2010, 117, 63-71.

7. Schoen, A.; Beck, B.; Sharma, R.; Dubé, E. Arsenic toxicity at low doses: Epidemiological and mode of action considerations. Toxicol. Appl. Pharmacol. 2004, 198, 253-267.

8. Wu, M.M.; Chiou, H.Y.; Wang, T.W.; Hsueh, Y.M.; Wang, I.H.; Chen, C.J.; Lee, T.C. Association of blood arsenic levels with increased reactive oxidants and decreased antioxidant capacity in a human population of northeastern Taiwan. Environ. Health Perspect. 2001, 109, 1011-1017.

9. Tapio, S.; Grosche, B. Arsenic in the aetiology of cancer. Mutat. Res. 2006, 612, 215-246.

10. Pei, Q.; Ma, N.; Zhang, J.; Xu, W.; Li, Y.; Ma, Z.; Li, Y.; Tian, F.; Zhang, W.; Mu, J.; et al. Oxidative DNA damage of peripheral blood polymorphonuclear leukocytes, selectively induced by chronic arsenic exposure, is associated with extent of arsenic-related skin lesions. Toxicol. Appl. Pharmacol. 2013, 266, 143-149.

11. Ahmed, S.; Ahsan, K.B.; Kippler, M.; Mily, A.; Wagatsuma, Y.; Hoque, A.M.; Ngom, P.T.; El Arifeen, S.; Raqib, R.; Vahter, M. In utero arsenic exposure is associated with impaired thymic function in newborns possibly via oxidative stress and apoptosis. Toxicol. Sci. 2012, 129, 305-314.

12. Vahter, M.; Concha, G. Role of metabolism in arsenic toxicity. Pharmacol. Toxicol. 2001, 89, $1-5$. 
13. Styblo, M.; Del Razo, L.M.; Vega, L.; Germolec, D.R.; LeCluyse, E.L.; Hamilton, G.A.; Reed, W.; Wang, C.; Cullen, W.R.; Thomas, D.J. Comparative toxicity of trivalent and pentavalent inorganic and methylated arsenicals in rat and human cells. Arch. Toxicol. 2000, 74, 289-299.

14. Petrick, J.S.; Ayala-Fierro, F.; Cullen, W.R.; Carter, D.E.; Vasken Aposhian, H. Monomethylarsonous acid (MMA(III)) is more toxic than arsenite in Chang human hepatocytes. Toxicol. Appl. Pharmacol. 2000, 163, 203-207.

15. Martinez, V.D.; Vucic, E.A.; Adonis, M.; Gil, L.; Lam, W.L. Arsenic biotransformation as a cancer promoting factor by inducing DNA damage and disruption of repair mechanisms. Mol. Biol. Int. 2011, 2011, 718974, doi: 10.4061/2011/718974.

16. Basu, A.; Mahata, J.; Gupta, S.; Giri, A.K. Genetic toxicology of a paradoxical human carcinogen, arsenic: A review. Mutat. Res. 2001, 488, 171-194.

17. Rossman, T.G. Mechanism of arsenic carcinogenesis: An integrated approach. Mutat. Res. 2003, 533, 37-65.

18. Li, J.H.; Rossman, T.G. Comutagenesis of sodium arsenite with ultraviolet radiation in Chinese hamster V79 cells. Biol. Met. 1991, 4, 197-200.

19. Lee, T.C.; Oshimura, M.; Barrett, J.C. Comparison of arsenic-induced cell transformation, cytotoxicity, mutation and cytogenetic effects in Syrian hamster embryo cells in culture. Carcinogenesis. 1985, 6, 1421-1426.

20. Kessel, M.; Liu, S.X.; Xu, A.; Santella, R.; Hei, T.K. Arsenic induces oxidative DNA damage in mammalian cells. Mol. Cell. Biochem. 2002, 234-235, 301-308.

21. Nesnow, S.; Roop, B.C.; Lambert, G.; Kadiiska, M.; Mason, R.P.; Cullen, W.R.; Mass, M.J. DNA damage induced by methylated trivalent arsenicals is mediated by reactive oxygen species. Chem. Res. Toxicol. 2002, 15, 1627-1634.

22. Jomova, K.; Jenisova, Z.; Feszterova, M.; Baros, S.; Liska, J.; Hudecova, D.; Rhodes, C.J.; Valko, M. Arsenic: Toxicity, oxidative stress and human disease. J. Appl. Toxicol. 2011, 31, 95-107.

23. Kitchin, K.T.; Wallace, K. Evidence against the nuclear in situ binding of arsenicals-Oxidative stress theory of arsenic carcinogenesis. Toxicol. Appl. Pharmacol. 2008, 232, 252-257.

24. Bau, D.T.; Wang, T.S.; Chung, C.H.; Wang, A.S.; Wang, A.S.; Jan, K.Y. Oxidative DNA adducts and DNA-protein cross-links are the major DNA lesions induced by arsenite. Environ. Health Perspect. 2002, 110, 753-756.

25. Hwang, E.S.; Kim, G.H. Biomarkers for oxidative stress status of DNA, lipids, and proteins in vitro and in vivo cancer research. Toxicology 2007, 229, 1-10.

26. Cooke, M.S.; Evans, M.D.; Dizdaroglu, M.; Lunec, J. Oxidative DNA damage: Mechanisms, mutation, and disease. FASEB J. 2003, 17, 1195-1214.

27. Ziech, D.; Franco, R.; Georgakilas, A.G.; Georgakila, S.; Malamou-Mitsi, V.; Schoneveld, O.; Pappa, A.; Panayiotidis, M.I. The role of reactive oxygen species and oxidative stress in environmental carcinogenesis and biomarker development. Chem. Biol. Interact. 2010, 188, 334-339.

28. Grollman, A.P.; Moriya, M. Mutagenesis by 8-oxoguanine: An enemy within. Trends Genet. 1993, 9, 246-249. 
29. Chung, C.J.; Huang, C.J.; Pu, Y.S.; Su, C.T.; Huang, Y.K.; Chen, Y.T.; Hsueh, Y.M. Polymorphisms in cell cycle regulatory genes, urinary arsenic profile and urothelial carcinoma. Toxicol. Appl. Pharmacol. 2008, 232, 203-209.

30. De Vizcaya-Ruiz, A.; Barbier, O.; Ruiz-Ramos, R.; Cebrian, M.E. Biomarkers of oxidative stress and damage in human populations exposed to arsenic. Mutat. Res. 2009, 674, 85-92.

31. Huang, C.Y.; Su, C.T.; Chung, C.J.; Pu, Y.S.; Chu, J.S.; Yang, H.Y.; Wu, C.C.; Hsueh, Y.M. Urinary total arsenic and 8-hydroxydeoxyguanosine are associated with renal cell carcinoma in an area without obvious arsenic exposure. Toxicol. Appl. Pharmacol. 2012, 262, 349-354.

32. Kligerman, A.D.; Malik, S.I.; Campbell, J.A. Cytogenetic insights into DNA damage and repair of lesions induced by a monomethylated trivalent arsenical. Mutat. Res. 2010, 695, 2-8.

33. Mourón, S.A.; Grillo, C.A.; Dulout, F.N.; Golijow, C.D. Induction of DNA strand breaks, DNA-protein crosslinks and sister chromatid exchanges by arsenite in a human lung cell line. Toxicol In Vitro 2006, 20, 279-285.

34. Liu, F.; Jan, K.Y. DNA damage in arsenite- and cadmium-treated bovine aortic endothelial cells. Free Radic. Biol. Med. 2000, 28, 55-63.

35. Qin, X.J.; Hudson, L.G.; Liu, W.; Timmins, G.S.; Liu, K.J. Low concentration of arsenite exacerbates UVR-induced DNA strand breaks by inhibiting PARP-1 activity. Toxicol. Appl. Pharmacol. 2008, 232, 41-50.

36. Colognato, R.; Coppedè, F.; Ponti, J.; Sabbioni, E.; Migliore, L. Genotoxicity induced by arsenic compounds in peripheral human lymphocytes analysed by cytokinesis-block micronucleus assay. Mutagenesis 2007, 22, 255-261.

37. Ghosh, P.; Basu, A.; Mahata, J.; Basu, S.; Sengupta, M.; Das, J.; Mukherjee, A.; Sarkar, A.K.; Mondal, L.; Ray, K.; Giri, A.K. Cytogenetic damage and genetic variants in the individuals susceptible to arsenic-induced cancer through drinking water. Int. J. Canc. 2006, 118, 2470-2478.

38. Ghosh, P.; Banerjee, M.; de Chaudhuri, S.; Das, J.K.; Sarma, N.; Basu, A.; Giri, A.K. Increased chromosome aberration frequencies in the Bowen's patients compared to non-cancerous skin lesions individuals exposed to arsenic. Mutat. Res. 2007, 632, 104-110.

39. Mahata, J.; Basu, A.; Ghoshal, S.; Sarkar, J.N.; Roy, A.K.; Poddar, G.; Nandy, A.K.; Banerjee, A.; Ray, K.; Natarajan, A.T.; et al. Chromosomal aberrations and sister chromatid exchanges in individuals exposed to arsenic through drinking water in West Bengal, India. Mutat. Res. 2003, 533, 133-143.

40. Martínez, V.; Creus, A.; Venegas, W.; Arroyo, A.; Beck, J.P.; Gebel, T.W.; Surrallés, J.; Marcos, R. Evaluation of micronucleus induction in a Chilean population environmentally exposed to arsenic. Mutat. Res. 2004, 564, 65-74.

41. Basu, A.; Ghosh, P.; Das, J.K.; Banerjee, A.; Ray, K.; Giri, A.K. Micronuclei as biomarkers of carcinogen exposure in populations exposed to arsenic through drinking water in West Bengal, India: A comparative study in three cell types. Cancer Epidemiol. Biomarkers Prev. 2004, 13, 820-827.

42. Basu, A.; Mahata, J.; Roy, A.K.; Sarkar, J.N.; Poddar, G.; Nandy, A.K.; Sarkar, P.K.; Dutta, P.K.; Banerjee, A.; Das, M.; Ray, K.; et al. Enhanced frequency of micronuclei in individuals exposed to arsenic through drinking water in West Bengal, India. Mutat. Res. 2002, $516,29-40$. 
43. Chakraborty, T.; Das, U.; Poddar, S.; Sengupta, B.; De, M. Micronuclei and chromosomal aberrations as biomarkers: A study in an arsenic exposed population in West Bengal, India. Bull. Environ. Contam. Toxicol. 2006, 76, 970-976.

44. Gonsebatt, M.E.; Vega, L.; Salazar, A.M.; Montero, R.; Guzmán, P.; Blas, J.; del Razo, L.M.; García-Vargas, G.; Albores, A.; Cebrián, M.E.; Kelsh, M.; Ostrosky-Wegman, P. Cytogenetic effects in human exposure to arsenic. Mutat. Res. 1997, 386, 219-228.

45. Tian, D.; Ma, H.; Feng, Z.; Xia, Y.; Le, X.C.; Ni, Z.; Allen, J.; Collins, B.; Schreinemachers, D.; Mumford, J.L. Analyses of micronuclei in exfoliated epithelial cells from individuals chronically exposed to arsenic via drinking water in inner Mongolia, China. J. Toxicol. Environ. Health A 2001, 64, 473-484.

46. Bartolotta, S.A.; Pacskowski, M.G.; Hick, A.; Carballo, M.A. Micronuclei assay in exfoliated buccal cells from individuals exposed to arsenic in Argentina. Arch. Environ. Contam. Toxicol. 2011, 61, 337-343.

47. Vuyyuri, S.B.; Ishaq, M.; Kuppala, D.; Grover, P.; Ahuja, Y.R. Evaluation of micronucleus frequencies and DNA damage in glass workers exposed to arsenic. Environ. Mol. Mutagen. 2006, 47, 562-570.

48. Marchiset-Ferlay, N.; Savanovitch, C.; Sauvant-Rochat, M.P. What is the best biomarker to assess arsenic exposure via drinking water? Environ. Int. 2012, 39, 150-171.

49. Liou, S.H.; Chen, Y.H.; Loh, C.H.; Yang, T.; Wu, T.N.; Chen, C.J.; Hsieh, L.L. The association between frequencies of mitomycin $\mathrm{C}$-induced sister chromatid exchange and cancer risk in arseniasis. Toxicol. Lett. 2002, 129, 237-243.

50. Mäki-Paakkanen, J.; Kurttio, P.; Paldy, A.; Pekkanen, J. Association between the clastogenic effect in peripheral lymphocytes and human exposure to arsenic through drinking water. Environ. Mol. Mutagen. 1998, 32, 301-313.

51. Hagmar, L.; Bonassi, S.; Stromberg, U.; Brogger, A.; Knudsen, L.S.; Norppa, H.; Reuterwall, C. Chromosomal aberrations in lymphocytes predict human cancer: A report from the European Study Group on Cytogenetic Biomarkers and Health (ESCH). Cancer Res. 1998, 58, 4117-4121.

52. Bonassi, S.; Znaor, A.; Ceppi, M.; Lando, C.; Chang, W.P.; Holland, N.; Kirsch-Volders, M.; Zeiger, E.; Ban, S.; Barale, R.; et al. An increased micronucleus frequency in peripheral blood lymphocytes predicts the risk of cancer in humans. Carcinogenesis 2007, 28, 625-631.

53. Federici, C.; Botto, N.; Manfredi, S.; Rizza, A.; Del Fiandra, M.; Andreassi, M.G. Relation of increased chromosomal damage to future adverse cardiac events in patients with known coronary artery disease. Am. J. Cardiol. 2008, 102, 1296-1300.

54. Warner, M.L.; Moore, L.E.; Smith, M.T.; Kalman, D.A.; Fanning, E.; Smith, A.H. Increased micronuclei in exfoliated bladder cells of individuals who chronically ingest arsenic-contaminated water in Nevada. Cancer Epidemiol. Biomarkers Prev. 1994, 3, 583-590.

55. Ferrario, D.; Collotta, A.; Carfi, M.; Bowe, G.; Vahter, M.; Hartung, T.; Gribaldo, L. Arsenic induces telomerase expression and maintains telomere length in human cord blood cells. Toxicology 2009, 260, 132-141. 
56. Li, H.; Engström, K.; Vahter, M.; Broberg, K. Arsenic exposure through drinking water is associated with longer telomeres in peripheral blood. Chem. Res. Toxicol. 2012, 25, 2333-2339.

57. Lai, Y.; Zhao, W.; Chen, C.; Wu, M.; Zhang, Z. Role of DNA polymerase beta in the genotoxicity of arsenic. Environ. Mol. Mutagen. 2011, 52, 460-468.

58. Hartwig, A.; Groblinghoff, U.D.; Beyersmann, D.; Natarajan, A.T.; Filon, R.; Mullenders, L.H. Interaction of arsenic(III) with nucleotide excision repair in UV-irradiated human fibroblasts. Carcinogenesis 1997, 18, 399-405.

59. Curnow, A.; Salter, L.; Morley, N.; Gould, D. A preliminary investigation of the effects of arsenate on irradiation-induced DNA damage in cultured human lung fibroblasts. J. Toxicol. Environ. Health A 2001, 63, 605-616.

60. Andrew, A.S.; Karagas, M.R.; Hamilton, J.W. Decreased DNA repair gene expression among individuals exposed to arsenic in United States drinking water. Int. J. Cancer 2003, 104, 263-268.

61. Andrew, A.S.; Burgess, J.L.; Meza, M.M.; Demidenko, E.; Waugh, M.G.; Hamilton, J.W.; Karagas, M.R. Arsenic exposure is associated with decreased DNA repair in vitro and in individuals exposed to drinking water arsenic. Environ. Health Perspect. 2006, 114, 1193-1198.

62. Schwerdtle, T.; Walter, I.; Mackiw, I.; Hartwig, A. Induction of oxidative DNA damage by arsenite and its trivalent and pentavalent methylated metabolites in cultured human cells and isolated DNA. Carcinogenesis 2003, 24, 967-974.

63. Ebert, F.; Weiss, A.; Bültemeyer, M.; Hamann, I.; Hartwig, A.; Schwerdtle, T. Arsenicals affect base excision repair by several mechanisms. Mutat. Res. 2011, 715, 32-41.

64. Sykora, P.; Snow, E.T. Modulation of DNA polymerase beta-dependent base excision repair in cultured human cells after low dose exposure to arsenite. Toxicol. Appl. Pharmacol. 2008, 228, 385-394.

65. Osmond, M.J.; Kunz, B.A.; Snow, E.T. Age and exposure to arsenic alter base excision repair transcript levels in mice. Mutagenesis 2010, 25, 517-522.

66. Snow, E.T.; Hu, Y.; Klein, C.; McCluskey, K.; Schuliga, M.; Sykora, P. Regulation of redox and DNA repair genes by arsenic: Low dose protection against oxidative stress? In Arsenic Exposure and Health Effects V; Chappel W.R., Abernathy C.O., Calderon R.L., Thomas D.J., Eds.; Elsevier Science: San Diego, CA, USA, 2003; pp. 305-319.

67. Valenzuela, O.L.; Drobná, Z.; Hernández-Castellanos, E.; Sánchez-Peña, L.C.; García-Vargas, G.G.; Borja-Aburto, V.H.; Stýblo, M.; del Razo, L.M. Association of AS3MT polymorphisms and the risk of premalignant arsenic skin lesions. Toxicol. Appl. Pharmacol. 2009, 239, 200-207.

68. Chung, C.J.; Hsueh, Y.M.; Bai, C.H.; Huang, Y.K.; Huang, Y.L.; Yang, M.H.; Chen, C.J. Polymorphisms in arsenic metabolism genes, urinary arsenic methylation profile and cancer. Canc. Causes Contr. 2009, 20, 1653-1661.

69. Schläwicke Engström, K.; Broberg, K.; Concha, G.; Nermell, B.; Warholm, M.; Vahter, M. Genetic polymorphisms influencing arsenic metabolism: Evidence from Argentina. Environ. Health Perspect. 2007, 115, 599-605.

70. Fujihara, J.; Soejima, M.; Yasuda, T.; Koda, Y.; Kunito, T.; Iwata, H.; Tanabe, S.; Takeshita, H. Polymorphic trial in oxidative damage of arsenic exposed Vietnamese. Toxicol. Appl. Pharmacol. 2011, 256, 174-178. 
71. Kundu, M.; Ghosh, P.; Mitra, S.; Das, J.K.; Sau, T.J.; Banerjee, S.; States, J.C.; Giri, A.K. Precancerous and non-cancer disease endpoints of chronic arsenic exposure: The level of chromosomal damage and XRCC3 T241M polymorphism. Mutat. Res. 2011, 706, 7-12.

72. Meza, M.M.; Yu, L.; Rodriguez, Y.Y.; Guild, M.; Thompson, D.; Gandolfi, A.J.; Klimecki, W.T. Developmentally restricted genetic determinants of human arsenic metabolism: Association between urinary methylated arsenic and CYT19 polymorphisms in children. Environ. Health Perspect. 2005, 113, 775-781.

73. Gomez-Rubio, P.; Meza-Montenegro, M.M.; Cantu-Soto, E.; Klimecki, W.T. Genetic association between intronic variants in AS3MT and arsenic methylation efficiency is focused on a large linkage disequilibrium cluster in chromosome 10. J. Appl. Toxicol. 2010, 30, 260-270.

74. Lindberg, A.L.; Kumar, R.; Goessler, W.; Thirumaran, R.; Gurzau, E.; Koppova, K.; Rudnai, P.; Leonardi, G.; Fletcher, T.; Vahter, M. Metabolism of low-dose inorganic arsenic in a central European population: Influence of sex and genetic polymorphisms. Environ. Health Perspect. 2007, 115, 1081-1086.

75. Agusa, T.; Iwata, H.; Fujihara, J.; Kunito, T.; Takeshita, H.; Minh, T.B.; Trang, P.T.; Viet, P.H.; Tanabe, S. Genetic polymorphisms in AS3MT and arsenic metabolism in residents of the Red River Delta, Vietnam. Toxicol. Appl. Pharmacol. 2009, 236, 131-141.

76. Gong, G.; O’Bryant, S.E. Low-level arsenic exposure, AS3MT gene polymorphism and cardiovascular diseases in rural Texas counties. Environ. Res. 2012, 113, 52-57.

77. Chen, J.W.; Wang, S.L.; Wang, Y.H.; Sun, C.W.; Huang, Y.L.; Chen, C.J.; Li, W.F. Arsenic methylation, GSTO1 polymorphisms, and metabolic syndrome in an arseniasis endemic area of southwestern Taiwan. Chemosphere 2012, 88, 432-438.

78. Hsieh, Y.C.; Lien, L.M.; Chung, W.T.; Hsieh, F.I.; Hsieh, P.F.; Wu, M.M.; Tseng, H.P.; Chiou, H.Y.; Chen, C.J. Significantly increased risk of carotid atherosclerosis with arsenic exposure and polymorphisms in arsenic metabolism genes. Environ. Res. 2011, 111, 804-810.

79. Agusa, T.; Kunito, T.; Tue, N.M.; Lan, V.T.; Fujihara, J.; Takeshita, H.; Minh, T.B.; Trang, P.T.; Takahashi, S.; Viet, P.H.; et al. Individual variations in arsenic metabolism in Vietnamese: The association with arsenic exposure and GSTP1 genetic polymorphism. Metallomics 2012, 4, 91-100.

80. Hsu, L.I.; Chiu, A.W.; Huan, S.K.; Chen, C.L.; Wang, Y.H.; Hsieh, F.I.; Chou, W.L.; Wang, L.H.; Chen, C.J. SNPs of GSTM1, T1, P1, epoxide hydrolase and DNA repair enzyme XRCC1 and risk of urinary transitional cell carcinoma in southwestern Taiwan. Toxicol. Appl. Pharmacol. 2008, 228, 144-155.

81. Hsu, L.I.; Chen, W.P.; Yang, T.Y.; Chen, Y.H.; Lo, W.C.; Wang, Y.H.; Liao, Y.T.; Hsueh, Y.M.; Chiou, H.Y.; Wu, M.M.; Chen, C.J. Genetic polymorphisms in glutathione S-transferase (GST) superfamily and risk of arsenic-induced urothelial carcinoma in residents of southwestern Taiwan. J. Biomed. Sci. 2011, 18, doi: 10.1186/1423-0127-18-51.

82. Lesseur, C.; Gilbert-Diamond, D.; Andrew, A.S.; Ekstrom, R.M.; Li, Z.; Kelsey, K.T.; Marsit, C.J.; Karagas, M.R. A case-control study of polymorphisms in xenobiotic and arsenic metabolism genes and arsenic-related bladder cancer in New Hampshire. Toxicol. Lett. 2012, 210, 100-106. 
83. Wang, Y.H.; Wu, M.M.; Hong, C.T.; Lien, L.M.; Hsieh, Y.C.; Tseng, H.P.; Chang, S.F.; $\mathrm{Su}$, C.L.; Chiou, H.Y.; Chen, C.J. Effects of arsenic exposure and genetic polymorphisms of p53, glutathione S-transferase M1, T1, and P1 on the risk of carotid atherosclerosis in Taiwan. Atherosclerosis 2007, 192, 305-312.

84. Chiou, H.Y.; Hsueh, Y.M.; Hsieh, L.L.; Hsu, L.I.; Hsu, Y.H.; Hsieh, F.I.; Wei, M.L.; Chen, H.C.; Yang, H.T.; Leu, L.C.; et al. Arsenic methylation capacity, body retention, and null genotypes of glutathione S-transferase M1 and T1 among current arsenic-exposed residents in Taiwan. Mutat. Res. 1997, 386, 197-207.

85. Steinmaus, C.; Moore, L.E.; Shipp, M.; Kalman, D.; Rey, O.A.; Biggs, M.L.; Hopenhayn, C.; Bates, M.N.; Zheng, S.; Wiencke, J.K.; Smith, A.H. Genetic polymorphisms in MTHFR 677 and 1298, GSTM1 and T1, and metabolism of arsenic. J. Toxicol. Environ. Health A 2007, 70, 159-170.

86. Agusa, T.; Iwata, H.; Fujihara, J.; Kunito, T.; Takeshita, H.; Minh, T.B.; Trang, P.T.; Viet, P.H.; Tanabe, S. Genetic polymorphisms in glutathione S-transferase (GST) superfamily and arsenic metabolism in residents of the Red River Delta, Vietnam. Toxicol. Appl. Pharmacol. 2010, 242, $352-362$.

87. Wu, M.M.; Chiou, H.Y.; Chen, C.L.; Hsu, L.I.; Lien, L.M.; Wang, C.H.; Hsieh, Y.C.; Wang, Y.H.; Hsueh, Y.M.; Lee, T.C.; et al. Association of heme oxygenase-1 GT-repeat polymorphism with blood pressure phenotypes and its relevance to future cardiovascular mortality risk: An observation based on arsenic-exposed individuals. Atherosclerosis 2011, 219, 704-708.

88. Wu, M.M.; Chiou, H.Y.; Lee, T.C.; Chen, C.L.; Hsu, L.I.; Wang, Y.H.; Huang, W.L.; Hsieh, Y.C.; Yang, T.Y.; Lee, C.Y.; et al. GT-repeat polymorphism in the heme oxygenase-1 gene promoter and the risk of carotid atherosclerosis related to arsenic exposure. J. Biomed. Sci. 2010, 17, doi: 10.1186/1423-0127-17-70.

89. De Chaudhuri, S.; Mahata, J.; Das, J.K.; Mukherjee, A.; Ghosh, P.; Sau, T.J.; Mondal, L.; Basu, S.; Giri, A.K.; Roychoudhury, S. Association of specific p53 polymorphisms with keratosis in individuals exposed to arsenic through drinking water in West Bengal, India. Mutat. Res. 2006, 601, 102-112.

90. Huang, C.Y.; Su, C.T.; Chu, J.S.; Huang, S.P.; Pu, Y.S.; Yang, H.Y.; Chung, C.J.; Wu, C.C.; Hsueh, Y.M. The polymorphisms of P53 codon 72 and MDM2 SNP309 and renal cell carcinoma risk in a low arsenic exposure area. Toxicol. Appl. Pharmacol. 2011, 257, 349-355.

91. Wood, T.C.; Salavagionne, O.E.; Mukherjee, B.; Wang, L.; Klumpp, A.F.; Thomae, B.A.; Eckloff, B.W.; Schaid, D.J.; Wieben, E.D.; Weinshilboum, R.M. Human arsenic methyltransferase (AS3MT) pharmacogenetics: Gene resequencing and functional genomics studies. J. Biol. Chem. 2006, 281, 7364-7373.

92. Drobná, Z.; Waters, S.B.; Walton, F.S.; LeCluyse, E.L.; Thomas, D.J.; Stýblo, M. Interindividual variation in the metabolism of arsenic in cultured primary human hepatocytes. Toxicol. Appl. Pharmacol. 2004, 201, 166-177.

93. Hernández, A.; Xamena, N.; Surrallés, J.; Sekaran, C.; Tokunaga, H.; Quinteros, D.; Creus, A.; Marcos, R. Role of the Met(287)Thr polymorphism in the AS3MT gene on the metabolic arsenic profile. Mutat. Res. 2008, 637, 80-92. 
94. Agusa, T.; Fujihara, J.; Takeshita, H.; Iwata, H. Individual variations in inorganic Arsenic metabolism associated with AS3MT genetic polymorphisms. Int. J. Mol. Sci. 2011, 12, 2351-2382.

95. Zakharyan, R.A.; Sampayo-Reyes, A.; Healy, S.M.; Tsaprailis, G.; Board, P.G.; Liebler, D.C.; Aposhian, H.V. Human monomethylarsonic acid (MMA(V)) reductase is a member of the glutathione-S-transferase superfamily. Chem. Res. Toxicol. 2001, 14, 1051-1057.

96. Whitbread, A.K.; Tetlow, N.; Eyre, H.J.; Sutherland, G.R.; Board, P.G. Characterization of the human Omega class glutathione transferase genes and associated polymorphisms. Pharmacogenetics 2003, 13, 131-144.

97. Paiva, L.; Marcos, R.; Creus, A.; Coggan, M.; Oakley, A.J.; Board, P.G. Polymorphism of glutathione transferase Omega 1 in a population exposed to a high environmental arsenic burden. Pharmacogenet. Genom. 2008, 18, 1-10.

98. Liu, J.; Chen, H.; Miller, D.S.; Saavedra, J.E.; Keefer, L.K.; Johnson, D.R.; Klaassen, C.D.; Waalkes, M.P. Overexpression of glutathione S-transferase II and multidrug resistance transport proteins is associated with acquired tolerance to inorganic arsenic. Mol. Pharmacol. 2001, 60, 302-309.

99. Brambila, E.M.; Achanzar, W.E.; Qu, W.; Webber, M.M.; Waalkes, M.P. Chronic arsenic-exposed human prostate epithelial cells exhibit stable arsenic tolerance: Mechanistic implications of altered cellular glutathione and glutathione S-transferase. Toxicol. Appl. Pharmacol. 2002, 183, 99-107.

100. Zimniak, P.; Nanduri, B.; Pikuła, S.; Bandorowicz-Pikuła, J.; Singhal, S.S.; Srivastava, S.K.; Awasthi, S.; Awasthi, Y.C. Naturally occurring human glutathione S-transferase GSTP1-1 isoforms with isoleucine and valine in position 104 differ in enzymic properties. Eur. J. Biochem. 1994, 224, 893-899.

101. McCarty, K.M.; Chen, Y.C.; Quamruzzaman, Q.; Rahman, M.; Mahiuddin, G.; Hsueh, Y.M.; Su, L.; Smith, T.; Ryan, L.; Christiani, D.C. Arsenic methylation, GSTT1, GSTM1, GSTP1 polymorphisms, and skin lesions. Environ. Health Perspect. 2007, 115, 341-345.

102. Beebe-Dimmer, J.L.; Iyer, P.T.; Nriagu, J.O.; Keele, G.; Mehta, S.; Meliker, J.R.; Lange, E.M.; Schwartz, A.G.; Zuhlke, K.A.; Schottenfeld, D.; Cooney, K.A. Genetic variation in Glutathione S-transferase omega-1, arsenic methyltransferase and methylene-tetrahydrofolate reductase, arsenic exposure and bladder cancer: A case-control study. Environ. Health. 2012, 11, doi: 10.1186/ 1476-069X-11-43.

103. Hill, J.W.; Evans, M.K. Dimerization and opposite base-dependent catalytic impairment of polymorphic S326C OGG1 glycosylase. Nucleic Acids Res. 2006, 34, 1620-1632.

104. Vodicka, P.; Stetina, R.; Polakova, V.; Tulupova, E.; Naccarati, A.; Vodickova, L.; Kumar, R.; Hanova, M.; Pardini, B.; Slyskova, J.; Musak, L.; de Palma, G.; Soucek, P.; Hemminki, K. Association of DNA repair polymorphisms with DNA repair functional outcomes in healthy human subjects. Carcinogenesis 2007, 28, 657-664.

105. States, J.C.; Srivastava, S.; Chen, Y.; Barchowsky, A. Arsenic and cardiovascular disease. Toxicol. Sci. 2009, 107, 312-323.

106. Morita, T. Heme oxygenase and atherosclerosis. Arterioscler. Thromb. Vasc. Biol. 2005, 25, $1786-1795$. 
107. Brydun, A.; Watari, Y.; Yamamoto, Y.; Okuhara, K.; Teragawa, H.; Kono, F.; Chayama, K.; Oshima, T.; Ozono, R. Reduced expression of heme oxygenase-1 in patients with coronary atherosclerosis. Hypertens. Res. 2007, 30, 341-348.

108. Del Razo, L.M.; Quintanilla-Vega, B.; Brambila-Colombres, E.; Calderón-Aranda, E.S.; Manno, M.; Albores, A. Stress proteins induced by arsenic. Toxicol. Appl. Pharmacol. 2001, $177,132-148$.

(C) 2013 by the authors; licensee MDPI, Basel, Switzerland. This article is an open access article distributed under the terms and conditions of the Creative Commons Attribution license (http://creativecommons.org/licenses/by/3.0/). 